\title{
CONFIRMATORY FACTOR ANALYSIS PADA PENGUKURAN KEHARMONISAN KELUARGA (FHS-24)
}

\author{
Nailul Fauziah ${ }^{182^{*}}$, Nurul Hartini ${ }^{1}$, Wiwin Hendriani ${ }^{1}$, Fajriyanthi ${ }^{1}$ \\ 1 Program Doktoral Fakultas Psikologi, Universitas Airlangga, Surabaya 60286, Indonesia \\ ${ }^{2}$ Fakultas Psikologi, Universitas Diponegoro, Semarang 50275, Indonesia
}

*)E-mail: nailulburhan@gmail.com

\begin{abstract}
Abstrak
Keharmonisan keluarga adalah ketahanan keluarga secara sosial psikologis, yang merupakan konsep penting sebagai penentu karakter anak dankepribadian positif anak. Namun, belum ditemukan publikasi validitas alat ukur keharmonisan keluarga di Indonesia. Hanya satu pengukuran keharmonisan keluarga dengan validitas dan reliabilitas yang telah dipublikasikan, yaitu FHS-24 (Family Harmony Scale) oleh Kavikondala et al. Penelitian ini bertujuan untuk mengidentifikasi alat ukur keharmonisan keluarga FHS-24 pada responden keluarga di Indonesia. Desain penelitian ini adalah cross-sectional, yaitu penelitian yang melibatkan beberapa variabel dan melihat hubungan antar variabel. Analisis data penelitian menggunakan metode SEM (Structure Equation Models) dengan CFA (Confirmatory Fit Analysis). Jumlah responden adalah 308 suami istri yang berasal dari berbagai daerah di Indonesia. Hasil yang diperoleh adalah pengukuran keharmonisan keluarga menggunakan skala keharmonisan keluarga FHS-24 merupakan model yang fit untuk digunakan pada keluarga di Indonesia. Hal tersebut dapat dilihat dari model structural (hubungan antar aspek menunjukkan angka yang valid) maupun model pengukuran (masing-masing pernyataan menunjukkan angka yang valid). Skala FHS-24 dapat digunakan untuk mengukur keharmonisan keluarga di Indonesia.
\end{abstract}

Kata kunci: CFA, FHS-24, Indonesia, keharmonisan keluarga, pengukuran

\section{Confirmatory Factor Analysis on Family Harmony Measurement (FHS-24)}

\begin{abstract}
Family harmony is the psychological resilience of the family, which is an important concept as a determinant of children's character and positive personality. However, research has not recorded the measurement of family harmony in Indonesia. There is only one published measurement of family harmony with validity and reliability, namely the FHS-24 (Family Harmony Scale) by Kavikondala et al. (2016). FHS-24 has not been widely adapted to other research, including in Indonesia. This encourages researchers to conduct studies on measuring family harmony in families in Indonesia. This study aims to identify the family harmony measurement tool (FHS-24) in families in Indonesia. The design of this research is cross-sectional that aims to determine whether or not the family harmony model is suitable for families in Indonesia, using the SEM (Structure Equation Model) with CFA (Confirmatory Fit Analysis) method. The number of subjects was 308 pairs of husbands and wives who came from various regions in Indonesia. The results indicate that the family harmony scale FHS-24 is a suitable model for use in families in Indonesia.
\end{abstract}

Keywords: CFA, family harmony, FHS-24, Indonesia, measurement

\section{PENDAHULUAN}

Family Harmony Scale, dikonstruksi oleh Kavikondala et al. (2016), digunakan untuk mengukur keharmonisan keluarga dengan mempertimbangkan faktor budaya dalam pengembangannya. Budaya merupakan faktor yang berpengaruh terhadap perilaku dan kesehatan mental. Karenanya, penting untuk mengakomodir faktor budaya dalam mengonstruksi sebuah alat ukur (Kavikondala et al., 2016). FSH dikembangkan berdasarkan konsep harmoni yang terdapat pada budaya
Cina. Dalam budaya ini, keharmonisan keluarga menekankan pada kedekatan, keselarasan, kerjasama dan mutualisme yang dipersepsi sebagai atribut yang paling berharga dalam sebuah hubungan keluarga. Hal ini merupakan faktor penting bagi kesehatan mental dan kesejahteraan individu (Kavikondala et al., 2016). Perbedaan makna harmoni pada budaya kolektivis dan individualis membuat konstruksi FSH menjadi urgen.

Indonesia dan Cina merupakan negara yang memiliki budaya kolektivis. Pada budaya 
kolektivis, konstruk keharmonisan keluarga berbeda dengan dukungan sosial yang berkembang di masyarakat individualis. Dukungan melalui penerimaan terhadap aspirasi individu merupakan hal yang dihargai sebagai karakteristik keluarga yang sehat pada budaya individualistis. Hal ini berbeda pada budaya kolektivis, dimana kewajiban terhadap keluarga merupakan prioritas utama. Keharmonisan keluarga pada masyarakat kolektivis menjadi faktor pelindung (protective factor) terhadap psikopatologi dan stress dalam kehidupan (Kavikondala et al., 2016).

Saat ini, fenomena keluarga tidak harmonis banyak terjadi di dalam lingkup masyarakat Indonesia. Hal ini diindikasikan oleh angka perceraian yang meningkat dari tahun ke tahun. Berdasarkan data Mahkamah Agung (MA) tahun 2017, terdapat 415.510 pasangan bercerai dimana angka ini meningkat sepanjang 2018 menjadi 444.358 dan meningkat kembali menjadi 480.618 pada tahun 2019. Angka tersebut menunjukkan peningkatan jumlah perceraian terus menerus setiap tahunnya (Akbar, 2020)

Lebih lanjut, melihat data pernikahan dan perceraian di Indonesia yang dirilis oleh Kementrian Agama RI, tampak pernikahan relatif tetap di angka dua juta dua ratusan ribu setiap tahun, sementara perceraian selalu meningkat hingga tembus di atas tiga ratus ribu kejadian setiap tahunnya (BKKBN, 2015). Artinya, jumlah perceraian di Indonesia mencapai seperempat dari jumlah pernikahan setiap tahunnya. Pada faktanya, perceraian memiliki dampak buruk baik pada perkembangan anak dan keluarga, seperti stres maupun konsep diri remaja (Asilah \& Hastuti, 2013; Mohammad, Muflikhati, \& Simanjuntak, 2019).

Fenomena di atas menjadi latar belakang peneliti untuk ikut berperan dalam upaya memperkuat ketahanan keluarga. Kementerian Pemberdayaan Perempuan dan Perlindungan Anak mendefinisikan ketahanan keluarga meliputi lima dimensi, yaitu: legalitas dan struktur keluarga; ketahanan fisik; ketahanan ekonomi; ketahanan sosial psikologi; dan ketahanan sosial budaya. Keharmonisan keluarga adalah ketahanan keluarga secara sosial psikologis (KPPPA \& BPS, 2016).

Istilah keharmonisan keluarga memang lebih banyak dikenal pada budaya Timur, seperti China, Hongkong juga Indonesia. Beberapa riset di Indonesia mendapatkan hasil bahwa keharmonisan keluarga berhubungan signifikan dengan berbagai variabel positif. Beberapa riset yang menyatakan adanya hubungan positif keharmonisan keluarga dengan beberapa variabel yang positif, antara lain: keharmonisan keluarga merupakan sumber dari kepribadian yang positif pada remaja. Keluarga yang memiliki kasih sayang, sikap saling pengertian, komunikasi terjalin baik, waktu yang banyak untuk keluarga lebih mudah membentuk kepribadian anak yang baik (Anjassari, Rustiyarso, \& Budjang, 2015). Riset lainnya menyebutkan adanya hubungan positif yang signifikan antara keharmonisan keluarga dengan kecerdasan emosional pada guru (Handayani dan Fauziah, 2016), keharmonisan keluarga dapat meningkatkan motivasi belajar melalui kenyamanan yang dirasakan anak dalam sebuah keluarga (Khadifa \& Sugihen, 2018; Rahayu, Zikra, \& Yusri, 2013; Partiyem, 2016, keharmonisan keluarga dapat meningkatkan spiritualitas (Herawati, Setyaningsih, \& Herlambang, 2019), dan juga mengurangi agresifitas remaja (Saputri, 2014) serta kenakalan remaja (Respati, Muhariati, \& Hasanah, 2016).

Riset lain menyatakan hubungan positif antara keharmonisan keluarga dengan wellbeing, seperti yang ditemukan Chuang (2005). Lam et al. (2012) juga menemukan efek dari ketidakharmonisan keluarga akan memunculkan anak-anak dengan permasalahan perilaku, performansi akademik yang buruk dan adanya perilaku anti sosial pada saat dewasa. Komunikasi dan penyesuaian keluarga merupakan faktor penting dari keharmonisan keluarga (Septiana, Krisnatuti, \& Simanjuntak, 2014).

Uraian di atas menunjukkan bahwa beberapa riset telah membuktikan secara empiris pentingnya keharmonisan dalam keluarga, yaitu memunculkan berbagai variabel dan karakter positif pada anak, serta mengurangi atau menghindarkan variabel/karakter negatif pada anak. Namun, riset tentang validasi pengukuran keharmonisan keluarga belum ditemukan publikasinya. Serta saat ini di Indonesia belum tersedia alat ukur keharmonisan keluarga yang sesuai untuk budaya kolektivis.

Berdasarkan kajian literatur yang telah dilakukan peneliti tentang konsep keharmonisan keluarga pada berbagai budaya, telah diperoleh beberapa hasil. Pertama, teori keharmonisan keluarga memiliki determinan yang berbeda-beda bergantung pada situasi dan konteks penelitian yang dilakukan. Masing- 
masing peneliti akan menggunakan pendekatan teori yang berbeda-beda sesuai dengan tujuan penelitian masing-masing (Fauziah, 2019).

Kedua, beberapa riset tentang keharmonisan keluarga menggunakan alat ukur yang diturunkan dari teori aspek-aspek DeFrain dan Stinnet (1999) dan mencoba menyusun sendiri tanpa berpatokan pada alat ukur yang sudah ada. DeFrain dan Stinnet (1999) belum membuat alat ukur keharmonisan keluarga secara spesifik, terpublikasi, serta terukur validitas dan reliabilitasnya. Tokoh lain yang mengungkapkan tentang keharmonisan keluarga adalah Moos dan Moos (1981) yang menyebut keharmonisan keluarga merupakan bagian dari teori besar yaitu Family Environment. Moos dan Moos (1981) membuat alat ukur keharmonisan keluarga dengan nama FRI (Family Relation Index) yang terdiri dari aspek kohesivitas, ekspresif, dan konflik. Moos dan Moos (1981) memandang bahwa keharmonisan keluarga semata-mata merupakan relasi sehingga Moos dan Moos menyebut alat ukur tersebut dengan FRI (Family Relation Index) bukan keharmonisan keluarga. Beberapa riset yang menggunakan FRI, antara lain Rioux et al. (2016) serta Perry, Harris, dan Minnes (2012). Alat ukur keharmonisan keluarga yang digunakan dalam riset-riset di atas tidak menjelaskan tentang pertimbangan budaya dalam pengembangannya.

Sejauh ini hanya terdapat satu artikel tentang alat ukur keharmonisan keluarga yang dipublikasi beserta pengukuran validitas dan reliabilitasnya yaitu skala keharmonisan keluarga FHS-24 (Kavikondala et al., 2016). FHS-24 terdiri dari 5 aspek, yaitu forbearance (kesabaran), conflict resolution (resolusi konflik), communication (komunikasi), identity (identitas keluarga), dan quality time (waktu yang berkualitas bersama keluarga). Kelima aspek diturunkan menjadi 24 pernyataan. Hasil uji validitas konvergen menunjukkan bahwa indikator pertanyaan dengan variabel dalam penelitian ini sudah valid. Validitas konvergen mempunyai makna bahwa seperangkat indikator mewakili satu variabel laten dan yang mendasari variabel laten tersebut. AVE (Average Variance Extracted) merupakan acuan untuk menunjukkan nilai reliabilitas sekaligus validitas diskriminan. Masing-masing variabel laten, yaitu communication, conflict resolution, forbearance, identity, dan quality time memiliki nilai AVE di atas 0,5. Angka tersebut menunjukkan bahwa masing-masing variabel memiliki validitas diskriminan dan reliabilitas yang baik. Nilai reliabilitas dapat dilihat dari nilai Cronbach's alpha, AVE, dan CR (Composite Reliability). Beberapa uraian di atas (fenomena meningkatnya angka perceraian, pentingnya variabel keharmonisan keluarga serta belum ditemukannya publikasi tentang pengukuran keharmonisan keluarga di Indonesia) menjadi celah peneliti untuk terus mengembangkan penelitian mengenai keharmonisan keluarga, khususnya tentang pengukuran keharmonisan keluarga di Indonesia. FHS yang dikembangkan oleh Kavikondala et al. (2016) telah teruji sesuai dengan budaya kolektivis. Oleh karenanya, Indonesia sebagai negara dengan budaya kolektivis perlu mengadaptasi alat ukur ini agar dapat digunakan untuk mengukur konstrak keharmonisan keluarga di Indonesia secara valid dan reliabel.

\section{METODE}

Penelitian ini merupakan penelitian kuantitatif dengan desain penelitian cross-sectional. Penelitian ini bertujuan untuk mengadaptasi skala FHS-24 dan menghitung fit atau tidaknya alat ukur FHS-24 pada responden keluarga di Indonesia. Pada perhitungan CFA first order, variabel keharmonisan keluarga merupakan variabel tergantung $(\mathrm{Y})$ dan aspek menjadi variabel bebas $(X)$, sedangkan pada perhitungan second order akan dilihat hubungan masing-masing indikator (pernyataan) pada masing-masing aspeknya. Selanjutnya, penelitian ini juga bertujuan untuk mengetahui validitas konstruk, diskriminan, dan konvergen. CFA digunakan untuk melakukan konfirmasi atas indikator untuk mengonfirmasi faktor. Evaluasi menggunakan CFA pada artikel ini menggunakan kriteria: (1) Model convergence dan acceptable range of parameter estimate dilakukan dengan melihat maximum likehood estimation (MLE), yang melibatkan proses berulang yaitu matrik kovarian yang diamati diperbandingkan dengan matrik teoritik untuk mengurangi adanya residu. Langkah ini dilakukan untuk mengetahui konvergen dari CFA; (2) Fit indices dilakukan untuk melihat goodness of fit data dari CFA. Fit indices terdiri dari absolute, incremental, dan parsimony fit indices.

Peneliti juga melakukan proses adaptasi skala karena setiap pernyataan dalam skala keharmonisan keluarga Kavikondala et al. (2016), perlu diterjemahkan ke dalam pemahaman bahasa Indonesia serta disesuaikan dengan karakteristik subyek yaitu keluarga Indonesia. Pembatasan definisi keluarga adalah suami dan istri. Adapun proses translasi alat ukur atau skala dilakukan melalui 
proses sesuai dengan pedoman International Test Commission (ITC) Guidelines for Test Adaptation (2016), mulai dari perizinan, forward translation, synthesis translation $(\mathrm{T})$, back translation (BT), expert judgment, dan uji keterbacaan.

Populasi penelitian ini adalah suami dan istri yang merupakan keluarga utuh. Pemilihan contoh menggunakan purposive sampling yang memenuhi kriteria yang telah ditentukan yaitu suami dan istri yang merupakan keluarga utuh. Berdasarkan perhitungan statistik menggunakan metode Monte Carlo simulation, untuk memperoleh data dengan $G$ power 0,8 agar data robust maka jumlah minimal responden yang repersentatif adalah 250 responden. Pengambilan data menggunakan teknik webpage-based self-completion questionnaire yaitu pendekatan pengambilan data yang dilakukan daring (dalam jaringan). Responden yang diperoleh sejumlah 308 responden yang terdiri dari 159 istri dan 149 suami yang berasal dari berbagai daerah di Indonesia. Pengambilan data dilakukan pada bulan Oktober 2020.

Instrumen yang digunakan adalah FHS-24 (Family Harmony Scale) yang dikembangkan oleh Kavikondala et al. (2016). FHS-24 terdiri dari lima aspek yaitu komunikasi, resolusi konflik, kesabaran (forbearance), identitas, dan waktu yang berkualitas. Contoh pernyataan pada aspek komunikasi adalah "anggota keluarga berbicara satu dengan yang lain". Aspek resolusi konflik dicontohkan pada pernyataan "anggota keluarga menyelesaikan masalah dengan damai". Aspek kesabaran contohnya adalah 'anggota keluarga saling memahami". Sementara itu, contoh pernyataan pada aspek identitas adalah "saya bangga akan keluarga saya". Contoh pernyataan pada aspek waktu yang berkualitas adalah "keluarga saya adalah tempat yang menyenangkan". Berdasarkan kelima aspek tersebut kemudian dijabarkan menjadi 24 pernyataan. Masingmasing pernyataan memiiki koefisien reabilitas di atas 0,94 dan validitas $0,62-0,86$. Responden mengisi pernyataan dengan memilih satu jawaban di antara lima pilihan sesuai skala Likert, yaitu sangat setuju, setuju, netral, tidak setuju dan sangat tidak setuju dengan skor masing-masing pilihan adalah 5, 4, 3, 2 dan 1 .

SPSS dan AMOS (Versi 26) digunakan sebagai alat analisis. SPSS digunakan untuk menganalisis kondisi demografi responden, sedangkan AMOS digunakan unuk analisis Structural Equation Modelling-Confirmatory
Factor Analysis (SEM CFA). SEM merupakan analisis yang terkemuka dalam berbagai riset karena SEM dapat mengalisis korelasi dari banyak variabel sekaligus; dapat mengetahui korelasi antara indikator dan aspek dalam sebuah variable; serta hubungan antara variabel tergantung, bebas, moderasi serta mediasi, baik hubungan langsung maupun tidak langsung dalam sebuah model pengukuran dan struktural (Ghozali, 2018). Confirmatory Factor Analysis (CFA) merupakan salah satu bagian dari metode SEM (Structural Equation Modelling) yang berfungsi untuk menguji dan menganalisis hubungan hipotesis yang sudah ada antara indikator dan variabel latennya (Hair et al., 2011). Indikator yang menunjukkan fit atau tidaknya alat ukur ditunjukkan oleh nilai Goodness-of-fit (GOF). Structural Equation Modelling (SEM) mempunyai tiga jenis utama indeks ukuran fit yaitu: absolute fit indices, incremental fit indices, dan parsimonious fit indices (Hair et al., 2011). Kriteria indeks ukuran fit pada penelitian ini adalah melihat absolute fit indices yaitu menentukan seberapa baik model apriori cocok dengan data sampel dan menunjukkan model mana yang memiliki kecocokan paling unggul. Indeks ini memberikan indikasi paling mendasar tentang seberapa baik teori yang diusulkan cocok dengan data. Yang termasuk dalam kategori ini adalah tes Chi-Squared, RMSEA, GFI, AGFI, RMR, dan SRMR. Analisis model melalui second order yaitu suatu analisis faktor konfirmatori yang memiliki dua jenjang analisis faktor yang menjelaskan korelasi faktor jenjang pertama dan kedua (Hair et al., 2011).

Validitas merupakan suatu pengukuran yang digunakan untuk menguji variabel-variabel indikator agar benar-benar signifikan dalam mencerminkan variabel konstruk atau laten. Validitas pengukuran terdiri atas validitas konvergen dan validitas diskriminan. Validitas konvergen ditentukan menggunakan parameter loading factor dan nilai AVE (Average Variance Extracted). Validitas diskriminan merupakan validitas yang menunjukkan bahwa dua konsep berbeda secara konspetual harus menunjukkan keterbedaan yang memadai. Maksudnya ialah seperangkat indikator yang digabung diharapkan tidak bersifat unidimensional. Masing-masing variabel dapat menunjukkan keterbedaan konsep (tidak memiliki definisi yang saling overlapping). Beberapa ukuran pada uji validitas disajikan pada bagian lamda $x$ (loading factor), pada format AMOS Validitas diskriminan, validitas konvergen serta validitas konstruk digunakan untuk melihat hubungan setiap indikator terhadap variabel latennya. 


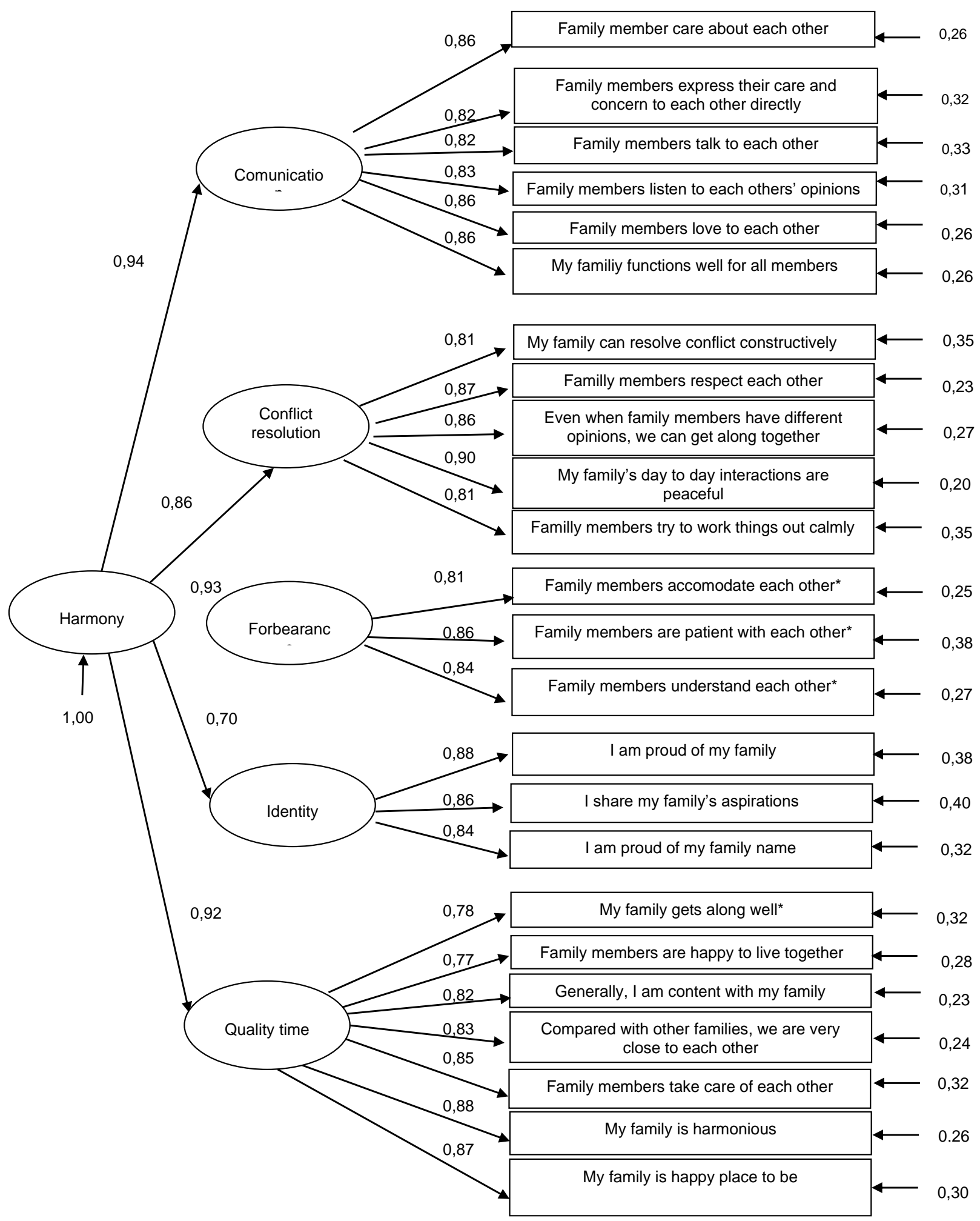

Gambar 1 Model second order CFA Family Harmony Scale (FHS-24)

\section{Skala Keharmonisan Keluarga FHS-24}

Pengembangan alat ukur keharmonisan keluarga dilakukan pada budaya China oleh Kavikondala et al. (2016). Langkah pertama (fase 1) adalah penentuan definisi dan pembentukan pernyataan. Dasar dalam pengembangan Family Harmony Scale (FHS24) adalah turunan dari dua riset kualitatif sebelumnya yang meneliti tentang keharmonisan keluarga dengan konteks budaya China (Chan, 2011; Lam et al., 2012). 
Tabel 1 Blue print FHS-24

\begin{tabular}{|c|c|c|}
\hline No. & Aspek & Pernyataan \\
\hline \multirow[t]{7}{*}{1.} & \multirow[t]{7}{*}{ Komunikasi } & $\begin{array}{l}\text { Anggota keluarga saling peduli } \\
\text { (X8) }\end{array}$ \\
\hline & & $\begin{array}{l}\text { Anggota keluarga } \\
\text { mengekspresikan }\end{array}$ \\
\hline & & $\begin{array}{l}\text { kepeduliannya satu dengan } \\
\text { yang lain secara langsung (X9) }\end{array}$ \\
\hline & & $\begin{array}{l}\text { Anggota keluarga berbicara } \\
\text { satu dengan yang lain }(\mathrm{X} 10)\end{array}$ \\
\hline & & $\begin{array}{l}\text { Anggota keluarga saling } \\
\text { mendengarkan opini/pendapat } \\
\text { satu sama lain (X13) }\end{array}$ \\
\hline & & $\begin{array}{l}\text { Anggota keluarga saling } \\
\text { mencintai (X23) }\end{array}$ \\
\hline & & $\begin{array}{l}\text { Keluarga saya berfungsi } \\
\text { dengan baik untuk semua } \\
\text { anggotanya (X16) }\end{array}$ \\
\hline \multirow[t]{5}{*}{2.} & \multirow[t]{5}{*}{$\begin{array}{l}\text { Resolusi } \\
\text { konflik }\end{array}$} & $\begin{array}{l}\text { Anggota keluarga saya dapat } \\
\text { menyelesaikan konflik secara } \\
\text { konstruktif (X17) }\end{array}$ \\
\hline & & $\begin{array}{l}\text { Anggota keluarga saya saling } \\
\text { menghormati (X18) }\end{array}$ \\
\hline & & $\begin{array}{l}\text { Meskipun anggota keluarga } \\
\text { memiliki pendapat yang } \\
\text { berbeda, kami tetap bisa rukun } \\
\text { (X19) }\end{array}$ \\
\hline & & $\begin{array}{l}\text { Interaksi sehari-hari keluarga } \\
\text { saya berlangsung damai (X20) }\end{array}$ \\
\hline & & $\begin{array}{l}\text { Anggota keluarga berusaha } \\
\text { menyelesaikan masalah } \\
\text { dengan tenang (X21) }\end{array}$ \\
\hline \multirow[t]{3}{*}{3.} & \multirow[t]{3}{*}{ Kesabaran } & $\begin{array}{l}\text { Anggota keluarga saling } \\
\text { mengakomodasi (X11) }\end{array}$ \\
\hline & & $\begin{array}{l}\text { Anggota keluarga saling sabar } \\
\text { (X12) }\end{array}$ \\
\hline & & $\begin{array}{l}\text { Anggota keluarga saling } \\
\text { memahami (X15) }\end{array}$ \\
\hline \multirow[t]{3}{*}{4.} & \multirow[t]{3}{*}{$\begin{array}{l}\text { Identitas } \\
\text { keluarga }\end{array}$} & $\begin{array}{l}\text { Saya bangga akan keluarga } \\
\text { saya (X2) }\end{array}$ \\
\hline & & $\begin{array}{l}\text { Saya membagikan inspirasi } \\
\text { keluarga saya (X3) }\end{array}$ \\
\hline & & $\begin{array}{l}\text { Saya bangga akan nama } \\
\text { keluarga saya (X4) }\end{array}$ \\
\hline \multirow[t]{7}{*}{5.} & \multirow{7}{*}{$\begin{array}{l}\text { Waktu yang } \\
\text { berkualitas }\end{array}$} & Keluarga saya rukun (X1) \\
\hline & & $\begin{array}{l}\text { Anggota keluarga senang } \\
\text { tinggal bersama (X5) }\end{array}$ \\
\hline & & $\begin{array}{l}\text { Secara umum saya puas } \\
\text { dengan keluarga saya (X6) }\end{array}$ \\
\hline & & $\begin{array}{l}\text { Jika dibandingkan dengan } \\
\text { keluarga lain, kami dekat satu } \\
\text { dengan yang lain (X7) }\end{array}$ \\
\hline & & $\begin{array}{l}\text { Anggota keluarga saling } \\
\text { menjaga satu dengan yang lain } \\
(\mathrm{X} 14)\end{array}$ \\
\hline & & Keluarga saya harmonis (X22) \\
\hline & & $\begin{array}{l}\text { Keluarga saya adalah tempat } \\
\text { yang menyenangkan }(\mathrm{X} 24)\end{array}$ \\
\hline
\end{tabular}

Fase kedua adalah uji coba sampai akhirnya mendapatkan 24 pernyataan valid dan realiabel. Fase kedua adalah mengujicobakan alat ukur pada masyarakat pada sekitar 17.461 responden, yang merupakan anggota dari 7.791 keluarga. Family Harmony Scale (FHS24) memiliki validitas $0,62-0,86$ dan reliabilitas 0,94 . Beberapa alasan penggunaan alat ukur FHS-24 pada riset adaptasi alat ukur ini adalah adanya publikasi FHS-24 yang mencakup validitas dan reliabilitas serta tahap-tahap pembuatan alat ukur secara jelas, uji coba telah dilakukan pada banyak responden (17.461 responden), serta definisi konsep yang digunakan sesuai dengan definisi keharmonisan keluarga dan secara spesifik menyebut variabel keharmonisan keluarga.

\section{Pengukuran FHS-24}

Tujuan dari model pengukuran adalah untuk menggambarkan seberapa baik indikatorindikator dapat digunakan sebagai instrumen pengukuran variabel laten. Konsep utama yang digunakan adalah pengukuran, validitas dan reliabilitas (Ghozali, 2014). Aspek keharmonisan keluarga Kavikondala et al. (2016) adalah communication, confict resolution, forbearance, identity, dan quality time. Model tersebut tersaji pada Gambar 1. Lebih lanjut, uraian blue print skala keharmonisan keluarga (FHS-24) tersaji pada Tabel 1:

FHS-24 memiliki 5 aspek dan 24 indikator. Masing-masing aspek terdiri dari indikator dengan jumlah yang berbeda-beda. Komunikasi memiliki 6 indikator, resolusi konflik memiliki 5 indikator, kesabaran memiliki 3 indikator, identitas keluarga terdiri dari 3 indikator, serta waktu yang berkualitas memiliki 7 indikator. Komunikasi merujuk pada kesempatan dan kesediaan anggota keluarga untuk terhubung satu sama lain. Adanya kesempatan bertemu langsung dan mengekspresikan perasaan secara verbal antar anggota keluarga merupakan syarat utama dalam komunikasi. Resolusi konflik merujuk pada kemampuan keluarga dalam menghadapi konflik yang terjadi dalam keluarga. Beberapa elemen yang umumnya berkontribusi terhadap konflik keluarga, yaitu gaya pengasuhan, nilai yang beragam, gaya hidup yang berbeda, dan kesulitan keuangan. Pasangan yang berasal dari gaya pengasuhan yang beragam sering menjadi sumber utama konflik pasangan. Kemampuan keluarga menyelesaikan perbedan yang terjadi dalam keluarga secara konstruktif menjadi kunci resolusi konflik dalam keluarga. 
Sementara itu, kesabaran merujuk pada aspek keharmonisan keluarga yang menggambarkan saling menghormati sebagai elemen kunci dalam membina keluarga yang harmonis. Aspek ini dibangun melalui hubungan timbal balik, menghormati nilai-nilai dan keberadaan yang beragam, serta penuh perhatian. Selanjutnya, aspek waktu yang berkualitas dimaknai sebagai adanya kesempatan menghabiskan waktu bersama dengan anggota keluarga. Kualitas dimaknai sebagai rasa kebersamaan serta kedekatan antar anggota keluarga sehingga anggota keluarga merasa nyaman tinggal bersama. Aspek terakhir yaitu identitas keluarga ditambahakan oleh Kavikondala et al. (2016) dengan pertimbangan perspektif budaya China. Identitas keluarga adalah penilaian respondentif dari anggota keluarga tentang kebanggaan dan harga diri (esteem) dari keluarga.

\section{Pengembangan Instrumen FH-24}

Kavikondala et al. (2016) menurunkan aspekaspek keharmonisan keluarga berdasarkan pada riset Lam et al. (2012). Proses pemilihan keseluruhan pernyataan pada awalnya adalah 52 pernyataan yang diujicobakan pada 543 partisipan, kemudian dilakukan pengukuran validitas dan reliabilitas alat ukurnya. Korelasi butir pernyataan dengan total $(r<0,4)$ yang menunjukkan pernyataan memiliki reliabilitas rendah menjadi pernyataan yang gugur dan menyisakan 39 pernyataan.

Tiga puluh sembilan pernyataan yang tersisa kemudian dianalisis menggunakan EFA untuk mendapatkan pola model yang fit untuk mengukur keharmonisna keluarga, dengan melihat apakah masing-masing indikator memang mencerminkan keempat variabel yang akan diukur. Analisis juga dilakukan dengan melakukan review judgment pada ahli dan anggota peneliti. Dasar pertimbangannya adalah adanya kesesuaian dan kesamaan budaya serta konsep tema/faktor dan akhirnya diperoleh 24 pernyataan final dari keharmonisan keluarga (FHS-24). Skor penilaian menggunakan skala Likert dengan lima pilihan, yaitu 5 untuk sangat setuju, 4 setuju, 3 netral, 2 tidak setuju dan 1 sangat tidak setuju. Semakin tinggi skor menunjukkan keharmonisan keluarga yang semakin besar. FHS-24 diujicobakan kepada 17.461 responden dan memiliki validitas $0,62-0,86$ dan reliabilitas 0,94 .

\section{Prosedur Adaptasi FHS-24}

Adapun proses translasi alat ukur atau skala dilakukan melalui proses sesuai dengan pedoman International Test Commission (ITC) Guidelines for Test Adaptation (2016) (Gambar 2). Pada tahap pertama, peneliti meminta ijin penggunaan skala pada tokoh pembuat Kavikondala et al. (2016) melalu email, kemudian dilanjutkan dengan tahapan selanjutnya yaitu Forward Translation.

Forward Translation. Forward Translation bertujuan untuk menerjemahkan alat ukur berbahasa Inggris ke Bahasa Indonesia dengan melibatkan dua translator.

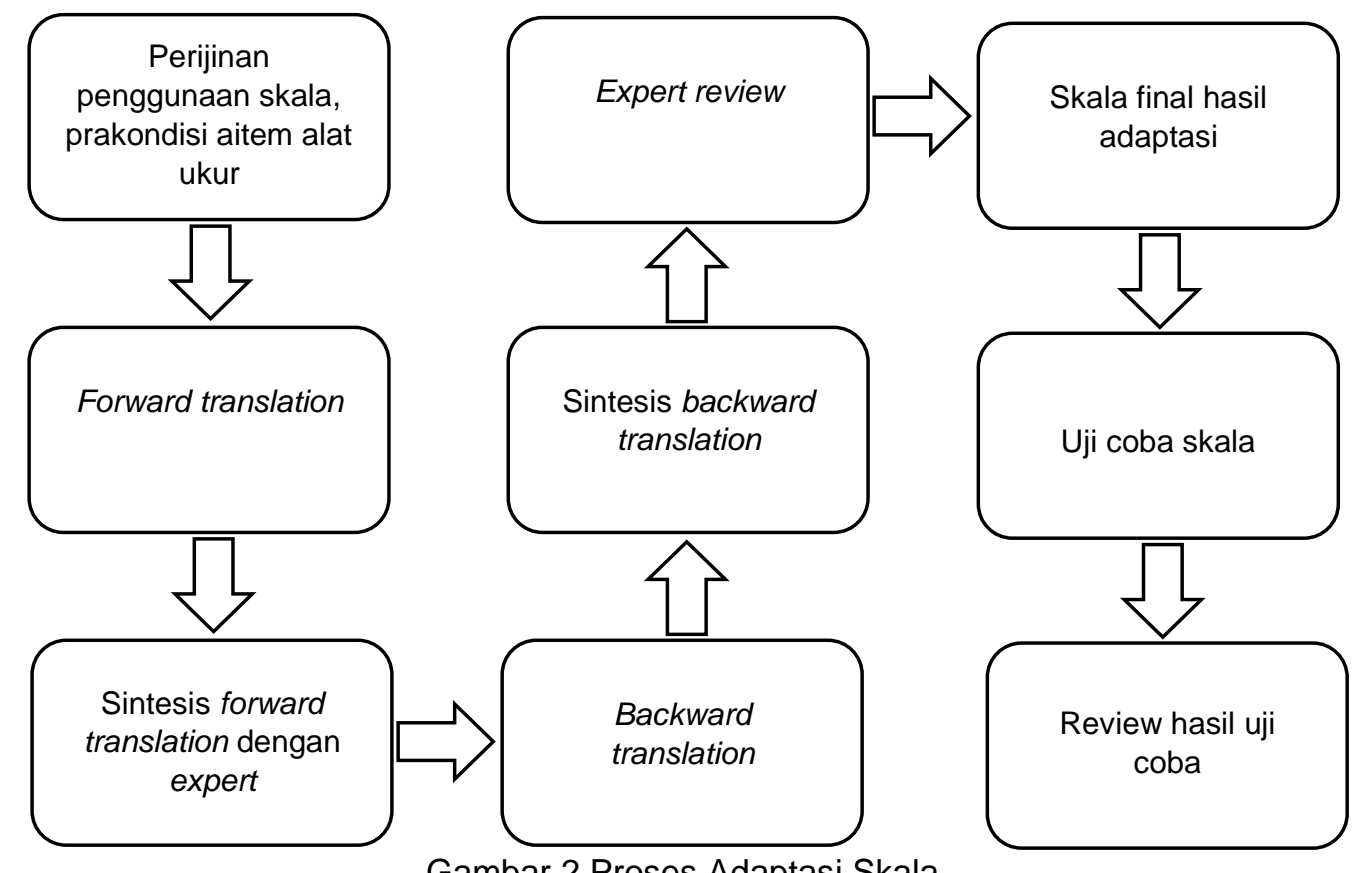

Gambar 2 Proses Adaptasi Skala 
Translator diminta untuk menerjemahkan 24 pernyataan skala keharmonisan keluarga secara independen. Instruksi pada translator adalah "Terjemahkan pernyataan-pernyataan ini ke bahasa Indonesia". Proses ini menghasilkan hasil translasi T1 dan T2.

Synthesis Translation (T). Hasil T1 dan T2 disintesiskan dengan cara membandingkan kedua hasil translasi. Pertimbangan untuk memilih hasil terjemahan adalah kesesuaian dengan konsep teoretis keharmonisan keluarga dan kelayakan ejaan bahasa Indonesia. Untuk memenuhi syarat ini, peneliti membandingkan data T1 dan T2, mencari perbedaan dan persamaannya kemudian dilanjutkan memberikan evaluasi tata bahasa. Hasil akhir T12 adalah terjemahan yang paling mendekati konteks dengan teori keharmonisan keluarga dan tata bahasa Indonesia yang baik.

Back Translation (BT). Setelah melakukan sintesis hasil terjemahan, T12 diberikan kepada back translator untuk diterjemahkan kembali ke dalam Bahasa Inggris sehingga peneliti dapat melihat derajat kesesuaiannya dengan pernyataan asli. Peneliti memberikan instruksi kepada setiap translator untuk menerjemahkan skala ini ke bahasa Inggris "sedekat-dekatnya". Peneliti juga menginstruksikan untuk tidak melakukan translasi berdasarkan interpretasi bebas, atau melakukan kondensasi (pemadatan) dari pernyataan yang kompleks. Sama seperti proses Forward Translation, peneliti menginstruksikan untuk mengerjakan translasi secara independen.

Expert Judgement. Setelah melalui tahap BT1 dan BT2 dan sebelum menyimpulkan pernyataan final, peneliti memberikan hasil T1, T2, T12, BT1, dan BT2 untuk dievaluasi oleh expert. Ada dua expert yang peneliti libatkan dalam pengujian ini. Satu expert untuk menilai kesesuaian konsep hasil terjemahan dengan konsep alat ukur asli dan dua ahli untuk menilai kesesuaian bahasa hasil terjemahan dengan tata bahasa Indonesia yang baik dan benar. Ketiga expert melakukan penilaian tentang ada tidaknya perbedaan makna antara translasi ataupun perbedaan dengan substansi.

Uji Keterbacaan. Uji Keterbacaan dilakukan untuk melihat mudah tidaknya kalimat pada pernyataan dipahami oleh responden penelitian. Semua responden menyatakan dapat memahami kalimat dalam pernyataan.

\section{HASIL}

Tabel 2 Data demografis responden

\begin{tabular}{|c|c|c|c|}
\hline Aspek & Karakteristik & $\begin{array}{c}\text { Frekuensi } \\
\text { (n) }\end{array}$ & $\begin{array}{c}\text { Persen } \\
(\%)\end{array}$ \\
\hline \multirow[t]{2}{*}{ Usia } & $<=40$ tahun & 200 & 64,9 \\
\hline & $>40$ tahun & 108 & 35,1 \\
\hline \multirow{4}{*}{$\begin{array}{l}\text { Jumlah } \\
\text { anak: }\end{array}$} & 0 & & \\
\hline & $1-2$ & 172 & 55,8 \\
\hline & $3-5$ & 85 & 27,7 \\
\hline & $>5$ & 1 & 0,3 \\
\hline \multirow[t]{5}{*}{ Pekerjaan } & $\begin{array}{l}\text { lbu Rumah } \\
\text { Tangga }\end{array}$ & 108 & 35,1 \\
\hline & Lain-lain, & 36 & 11,7 \\
\hline & $\begin{array}{l}\text { Pegawai } \\
\text { Negeri/ } \\
\text { Tentara/ } \\
\text { Polisi/BUMN }\end{array}$ & 96 & 31,2 \\
\hline & $\begin{array}{l}\text { Pegawai } \\
\text { Swasta }\end{array}$ & 33 & 10,7 \\
\hline & Wiraswasta & 35 & 11,4 \\
\hline \multirow[t]{6}{*}{$\begin{array}{l}\text { Pendidikan } \\
\text { Terakhir }\end{array}$} & $\begin{array}{l}\text { SMP atau } \\
\text { sederajat }\end{array}$ & 6 & 1,9 \\
\hline & $\begin{array}{l}\text { SMA atau } \\
\text { sederajat }\end{array}$ & 27 & 8,8 \\
\hline & $\begin{array}{l}\text { D-3 atau } \\
\text { sederajat }\end{array}$ & 25 & 8,1 \\
\hline & $\begin{array}{l}\text { S-1 atau } \\
\text { sederajat }\end{array}$ & 161 & 52,3 \\
\hline & $\begin{array}{l}\text { S-2 atau } \\
\text { spesialis }\end{array}$ & 83 & 26,9 \\
\hline & S-3 & 6 & 1,9 \\
\hline \multirow{4}{*}{$\begin{array}{l}\text { Usia } \\
\text { Pernikahan } \\
\text { (tahun) }\end{array}$} & $0-10$ & 145 & 47,1 \\
\hline & $11-20$ & 123 & 40,0 \\
\hline & $20-30$ & 38 & 12,3 \\
\hline & $30-40$ & 2 & 0,6 \\
\hline \multirow[t]{3}{*}{$\begin{array}{l}\text { Penghasilan } \\
\text { per bulan }\end{array}$} & $\begin{array}{l}\text { Rp1.000.000 } \\
\text { s/d Rp15.000. } \\
000\end{array}$ & 228 & 74 \\
\hline & $\begin{array}{l}\text { Rp15.000.000 } \\
\text { s/d } \\
\text { Rp30.000.000 }\end{array}$ & 70 & 22,7 \\
\hline & $>$ Rp30.000.000 & 10 & 3,2 \\
\hline
\end{tabular}

\section{Data Demografi Responden Penelitian}

Peneliti melakukan analisis data menggunakan SPSS bertujuan untuk mengetahui data demografi responden penelitian. Hasil demografi responden penelitian tersaji pada Tabel 2.

Karakteristik Keluarga. Berdasarkan data demografi, responden penelitian ini terdiri dari 308 responden pasangan suami istri yang sebagian besar berusia di atas 40 tahun (65\%) dengan jumlah anak 1-2 orang. Tingkat pendidikan menunjukkan angka tertinggi pada S-1 (52,3\%) dengan jumlah 161 responden dan S2 sebanyak 83 responden, serta tidak ditemukan data dengan tingkat pendidikan 
responden lulusan SD (0\%). Pengambilan data yang dilakukan secara online (dalam jaringan) membutuhkan keterampilan penggunaan gawai dalam pengerjaan, yang juga membutuhkan pemahaman dan tingkat pendidikan yang relatif tinggi. Hal inilah yang memungkinkan tingkat pendidikan responden dalam penelitian ini relatif tinggi.

Usia Perkawinan sebagian besar responden berada pada rentang 0-10 tahun yaitu 145 responden $(47 \%)$ dan terbesar kedua adalah usia perkawinan $10-20$ tahun (40\%). Data ini menunjukkan bahwa responden penelitian ini beragam jika dilihat dari usia perkawinan. Lebih lanjut, terdapat responden dengan usia perkawinan di atas 20 tahun. Hal tersebut menunjukkan pengambilan data yang beragam dan cukup mewakili usia perkawinan yang terdapat di keluarga di Indonesia, mulai dari responden yang usia perkawinannya berada pada tahap awal/adaptasi (1-10 tahun usia perkawinan) maupun yang stabil (lebih dari 10 tahun usia perkawinan).

Penghasilan perbulan menunjukkan data bahwa sebagian besar responden berpenghasilan hingga Rp15.000.000,00. Berdasarkan keseluruhan data, hal tersebut cukup mewakili dari gambaran umum tingkat ekonomi keluarga yang ada di Indonesia.

\section{Hasil Studi 1: Hasil Confirmatory Factor Analysis (CFA) Skala Keharmonisan Keluarga (FHS-24)}

Hasil analisis CFA menggunakan program AMOS 26 ditunjukkan oleh Tabel 3.

Tabel 3 Hasil pengujian model keseluruhan

\begin{tabular}{lcl}
\hline $\begin{array}{c}\text { Ukuran uji } \\
\text { kecokkan model } \\
\text { secara }\end{array}$ & $\begin{array}{c}\text { Nilai patokan } \\
\text { untuk } \\
\text { kecocokkan } \\
\text { model }\end{array}$ & $\begin{array}{l}\text { Kecocokkan } \\
\text { model } \\
\text { terhadap } \\
\text { data }\end{array}$ \\
\hline P- Value $=0,159$ & $\geq 0,05$ & Good Fit \\
$\mathrm{RMSEA}=0,021$ & $\leq 0,08$ & Good Fit \\
$\mathrm{NFI}=0,969$ & $\geq 0,95$ & Good Fit \\
$\mathrm{NNFI} / \mathrm{TLI}=0,995$ & $\geq 0,95$ & Good Fit \\
$\mathrm{CFI}=0,997$ & $\geq 0,90$ & Good Fit \\
$\mathrm{IFI}=0,997$ & $\geq 0,90$ & Good Fit \\
$\mathrm{RFI}=0,952$ & $\geq 0,90$ & Good Fit \\
$\mathrm{RMR}=0,019$ & $\leq 0,05$ & Good Fit \\
$\mathrm{GFI}=0,942$ & $\geq 0,90$ & Good Fit \\
$\mathrm{AGFI}=0,903$ & $\geq 0,90$ & Good Fit \\
\hline
\end{tabular}

Keterangan: P-value=signifikansi; RMSEA $=$ Root Mean Square Error of Approximation; NFI=Normed Fit Index; $\mathrm{NNFI} / \mathrm{TLI}=$ Tucker Lewis Index; $\mathrm{CFI}=$ Comparative Fit Index; IFI=Incremetal Fit Index; RFI=Relative Fit Index; $\mathrm{RMR}=$ Root Mean Square Residual; GFI=Goodness of Fit Indeks; AGFI=Adjusted Goodness Fit of Index
Tabel 4 Loading factor FHS-24

\begin{tabular}{|c|c|c|c|}
\hline Indikator & & Variabel laten & $\begin{array}{l}\text { Loading } \\
\text { factor }\end{array}$ \\
\hline Forbearance & $<---$ & Harmony & 0,892 \\
\hline Quality time & $<---$ & Harmony & 0,923 \\
\hline $\begin{array}{l}\text { Conflict } \\
\text { resolution }\end{array}$ & $<---$ & Harmony & 0,764 \\
\hline Communication & $<---$ & Harmony & 0,722 \\
\hline Identity & $<---$ & Harmony & 0,878 \\
\hline X8 & $<---$ & Communication & 0,901 \\
\hline X9 & $<---$ & Communication & 0,908 \\
\hline $\mathrm{X} 10$ & $<---$ & Communication & 0,886 \\
\hline $\mathrm{X} 13$ & $<---$ & Communication & 0,787 \\
\hline X23 & $<---$ & Communication & 0,845 \\
\hline $\mathrm{X} 21$ & $<---$ & $\begin{array}{l}\text { Conflict } \\
\text { resolution }\end{array}$ & 0,748 \\
\hline X20 & $<---$ & $\begin{array}{l}\text { Conflict } \\
\text { resolution }\end{array}$ & 0,926 \\
\hline X19 & $<---$ & $\begin{array}{l}\text { Conflict } \\
\text { resolution }\end{array}$ & 0,951 \\
\hline $\mathrm{X} 18$ & $<---$ & $\begin{array}{l}\text { Conflict } \\
\text { resolution }\end{array}$ & 0,851 \\
\hline $\mathrm{X} 17$ & $<---$ & $\begin{array}{l}\text { Conflict } \\
\text { resolution }\end{array}$ & 0,676 \\
\hline X15 & $<---$ & Forbearance & 0,811 \\
\hline $\mathrm{X} 11$ & $<---$ & Forbearance & 0,747 \\
\hline $\mathrm{X} 12$ & $<---$ & Forbearance & 0,890 \\
\hline X4 & $<---$ & Identity & 0,709 \\
\hline X3 & $<--$ & Identity & 0,836 \\
\hline $\mathrm{X} 2$ & $<---$ & Identity & 0,856 \\
\hline $\mathrm{X} 1$ & $<---$ & Quality time & 0,870 \\
\hline $\mathrm{X} 6$ & $<---$ & Quality time & 0,804 \\
\hline$\times 5$ & $<---$ & Quality time & 0,865 \\
\hline X7 & $<--$ & Quality time & 0,831 \\
\hline $\mathrm{X} 14$ & $<---$ & Quality time & 0,848 \\
\hline X22 & $<---$ & Quality time & 0,886 \\
\hline X24 & $<---$ & Quality time & 0,852 \\
\hline
\end{tabular}

Keterangan: $\mathrm{X} 1-24$ = indikator atau pernyataan

Hasil menunjukkan beberapa parameter yang menunjukkan bahwa model fit untuk mengukur keharmonisan keluarga.Kline (2005) merekomendasikan indeks yang harus dilaporkan adalah uji Chi-Square/P-value, RMSEA, CFI dan SRMR. Nilai $p$-value 0,159 menjadi standar nilai yang menunjukkan kesesuaian model secara keseluruhan. RMSEA menunjukkan interval kepercayaan nilai model fit, standarnya adalah di bawah 0,08 , sehingga model ini disebut fit. Angka CFI di atas 0,9 juga menunjukkan model yang fit. Secara keseluruhan standar parmeter yang digunakan 
untuk mengukur tingkat kesesuaian model adalah fit.

\section{Hasil Studi 2: Validitas Diskriminan, Validitas Konvergen dan Validitas Konstruk}

Validitas konvergen ditentukan menggunakan parameter loading factor dan nilai AVE (Average Variance Extracted). Beberapa ukuran pada uji validitas disajikan pada bagian lambda (loading factor), pada format AMOS (Tabel 4). Hasil yang tersaji pada Tabel 4 menunjukkan adanya nilai loading factor yang muncul antara variabel dengan indikator pertanyaan memiliki nilai yang tidak sama, dapat dilihat nilai loading factor berada di atas 0,6 yang menandakan hubungan yang sesuai antara variabel laten dan indikator. Oleh karenanya, dapat disimpulkan berdasarkan hasil uji validitas konvergen bahwa indikator pertanyaan dengan variabel dalam penelitian ini sudah valid. Validitas konvergen mempunyai makna bahwa seperangkat indikator mewakili satu variabel laten dan yang mendasari variabel laten tersebut.

Variabel Harmony pada fist order tercermin melalui aspek-aspek forbearance, quality time, identity, conflict resolution, dan communication. Pada hasil analisis second order, communication tercermin melalui indikator $\mathrm{X} 8$, $X 9, X 10, X 13$, serta $X 23$. Conflict resolution tercermin melalui indikator X17, X18, X19, X20, dan $\mathrm{X} 21$. Forberance tercermin melalui indikator $\mathrm{X} 11, \mathrm{X} 12$ dan $\mathrm{X} 15$. Identity tercermin melalui indikator X2, X3 dan X4. Quality time tercermin melalui indikator $\mathrm{X} 1, \mathrm{x} 5, \mathrm{X} 6, \mathrm{X} 7, \mathrm{X} 14$, $X 22$ dan X24. Masing-masing aspek dan indikator telah sesuai dengan Gambar 1 dalam model keharmonisan keluarga (FHS-24). Langkah selanjutnya adalah melihat diskriminan seperti yang tersaji pada Tabel 5 . Lebih lanjut, AVE (Average Variance Extracted) merupakan acuan untuk menunjukkan nilai reliabilitas, sekaligus validitas diskriminan.

Tabel 5 Daftar composit reliability dan AVE

\begin{tabular}{lccc}
\hline $\begin{array}{l}\text { Laten } \\
\text { Variabel }\end{array}$ & $\begin{array}{c}\text { Cronba } \\
\text { ch's } \\
\text { Alpha }\end{array}$ & $\begin{array}{c}\text { Composit } \\
e \\
\text { Reliability }\end{array}$ & $\begin{array}{c}\text { Average } \\
\text { Variance } \\
\text { Extracted (AVE) }\end{array}$ \\
\hline $\begin{array}{l}\text { Commu } \\
\text { nication }\end{array}$ & 0,939 & 0,954 & 0,805 \\
$\begin{array}{l}\text { Conflict } \\
\text { resolutio }\end{array}$ & 0,922 & 0,941 & 0,763 \\
$\begin{array}{l}n \\
\text { Forbear }\end{array}$ & 0,857 & 0,913 & 0,778 \\
$\begin{array}{l}\text { ance } \\
\text { ldentity }\end{array}$ & 0,871 & 0,921 & 0,794 \\
$\begin{array}{l}\text { Quality } \\
\text { time }\end{array}$ & 0,949 & 0,958 & 0,766
\end{tabular}

Masing-masing variabel laten, yaitu communication, conflict resolution, forbearance, identity, dan quality time memiliki nilai AVE di atas 0,5 . Angka tersebut menunjukkan masingmasing variabel memiliki validitas diskriminan dan reliabilitas yang baik. Nilai reliabilitas dapat dilihat dari nilai Cronbach's alpha, AVE, dan CR (Composite Reliability). Nilai yang tertera pada tabel di atas menunjukkan bahwa nilai Cronbach's alpha serta CR masing-masing di atas 0,7, maka masing-masing variabel laten merupakan variabel yang reliabel untuk digunakan sebagai pengukuran keharmonisan keluarga.

\section{PEMBAHASAN}

Penelitian ini menggunakan konsep keharmonisan keluarga menurut Kavikondala et al. (2016) yang merujuk pada suatu penilaian subjektif tentang relasi antaranggota keluarga sehingga tercipta perasaan nyaman dan aman dalam keluarga. Komponen keharmonisan keluarga menurut Kavikondala et al. (2016) adalah adanya komunikasi, resolusi konflik, kesabaran, waktu yang berkualitas, serta identitas keluarga.

Penelitian ini bertujuan untuk mengidentifikasi alat ukur keharmonisan keluarga (FHS-24) pada responden keluarga di Indonesia. Secara keseluruhan hasil analisis yang diperoleh adalah alat ukur keharmonisan keluarga (FHS24) merupakan alat ukur yang fit dan dapat digunakan dalam mengukur keharmonisan keluarga pada responden keluarga di Indonesia.

Hasil analisis SEM yang digunakan untuk mengukur model struktural (hubungan antara indikator dan variabel) dan model pengukuran (hubungan antar variabel laten), menunjukkan hubungan antara dimensi/aspek dalam keharmonisan keluarga. Hal tersebut terlihat dari hasil analisis pada berbagai uji Goodness of Fit (GoF) yang dilakukan, baik nilai RMSEA, $\mathrm{NFI}, \mathrm{GFI}$, dan lain-lain. Sementara itu, model struktural menunjukkan hubungan antara indikator dan variabel laten atau mengetahui seberapa besar kontribusi masing-masing indikator pada variabel laten. Hasil yang diperoleh ditunjukkan melalui loading factor yang terdapat dari masing-masing hubungan.

Pertama, pada 5 faktor yang terdapat pada FHS-24 yaitu forbearance (kesabaran), quality time, conflict resolution, communication, serta identity; angka loading factor terbesar ditunjukkan oleh aspek quality time sebesar 
0,923. Hal tersebut menunjukkan bahwa aspek quality time merupakan aspek yang paling berpengaruh dalam variabel keharmonisan keluarga. Hasil penelitian ini sesuai dengan riset Lombardi (2021) yang menyatakan bahwa fungsi kualitas dalam relasi keluarga adalah penting, termasuk dalam hal waktu yang berkualitas yang dihabiskan dengan keluarga menentukan relasi orang tua-anak, serta pengasuhan ibu-anak. Waktu yang berkualitas akan menciptakan hubungan yang hangat antaranggota keluarga. Adanya waktu yang berkualitas bukan semata-mata jumlah waktu yang dihabiskan bersama, namun kualitaslah yang lebih diutamakan.

Aspek komunikasi banyak dijelaskan merupakan aspek yang berpengaruh penting pada keharmonisan keluarga. Hal tersebut sesuai dengan penelitian Asoodeh et al. (2011), Bakar dan Aftanorhan (2015), Soltani, Hosseini, dan Mahmoodi (2012), serta Zarnghash dan Zarnaghash (2012). Komunikasi memengaruhi kesehatan mental anak dan orang tua dalam sebuah keluarga. Komunikasi juga merupakan salah satu faktor yang memengaruhi pembentukan identitas anak. Namun, pada variabel keharmonisan keluarga (FHS-24), komunikasi terdapat pada urutan terakhir berdasarkan hasil loading factor. Hal tersebut merupakan temuan menarik karena semua referensi mengungkapkan pentingnya komunikasi dalam keluarga. Namun, karena pernyataan lebih pada komunikasi yang ekspresif secara langsung, langsung menyampaikan ketidaksukaan, saling berbicara langsung, dan lainnya, maka memungkinkan munculnya ketidaksesuaian pola komunikasi verbal dengan budaya Indonesia. Hal tersebut sesuai dengan hasil riset Rizak (2018) yang mengungkapkan bahwa adanya pola komunikasi antara budaya memunculkan perilaku, nilai, interaksi, rasa yang berbeda, termasuk dalam pola komunikasi verbal. Budaya Timur lebih menekankan ketergantungan, harmoni, rendah hati, dan konformitas; dengan pola komunikasi tidak langsung dan tidak eksplisit (high context communication). Sementara itu, budaya Barat lebih menekankan penyelesaikan konflik, asertif, kepercayaan diri, dan otonomi dengan pola komunikasi langsung dan eksplisit (low context communication) (Nur \& Bahriyah, 2008)

Berdasarkan loading factor, secara berurutan dari yang terbesar hingga terkecil, variabel yang memengaruhi keharmonisan keluarga adalah: quality time, forbearance, identity, conflict resolution, dan communication. Namun, secara umum, keseluruhan aspek menunjukkan pengaruh yang signifikan pada variabel keharmonisan keluarga. Kebersamaan merupakan hal yang penting bagi masyarakat budaya komunal. Kebutuhan untuk berkumpul bersama keluarga merupakan cara untuk menghilangkan stress sekaligus mendapatkan dukungan dari keluarga (Nuraini \& Hartini, 2021).

Identitas keluarga (identity) merupakan hal yang penting dalam keluarga. Hal tersebut sesuai dengan hasil beberapa riset yang menyatakan bahwa peran, nilai serta kepercayaan yang terdapat pada suatu lingkungan akan memengaruhi identitas keluarga dan pada akhirnya akan memengaruhi pola pikir, tata cara dalam mengasuh anak, pola komunikasi bahkan sampai berpengaruh pada kesehatan mental keluarga (Sharif et al., 2015; Soltani et al., 2012; Wilson \& Tonner, 2020).

Kedua, loading factor terbesar pada aspek komunikasi ditunjukkan oleh indikator $\mathrm{X} 9$, yaitu "mengekspresikan perasaan secara langsung pada anggota keluarga". Temuan ini menarik karena budaya Timur yang lebih cenderung tidak ekpresif dalam pola berkomunikasi. Hal ini menunjukkan bahwa bagaimanapun komunikasi secara ekspresif (langsung) sangat penting dalam pola berkomunikasi dalam keluarga. Hal tersebut sesuai dengan penelitian Berlianti et al. (2016) yang menunjukkan pentingnya komunikasi langsung antara orang tua-remaja untuk membina hubungan yang baik tidak terjadi kesalahpahaman dalam memahami perasaan ataupun keinginan anggota keluarga.

Aspek conflict resolution dengan loading factor terbesar adalah "meskipun berbeda pendapat, tetap rukun satu sama lain" (X19). Sementara itu, forbearance (kesabaran) ditunjukkan oleh indikator yaitu "anggota keluarga saling memahami" (X12). Pada aspek identity, loading factor terbesar ditunjukkan oleh indikator "anggota keluarga saling memahami" (X2). Sementara itu, aspek quality time dengan loading factor terbesar ditunjukkan oleh indikator "anggota keluarga saling menjaga satu sama lain" (X22). Nilai-nilai tersebut tercermin pula dalam penelitian Pasaribu, Hastuti, dan Alfiasari (2013) yang meneliti tentang pola pengasuhan orang tua yang otoritatif (demokratis) dan sosialisasi positif dari ibu kepada anak yang cenderung memiliki interaksi dengan menunjukkan penghargaan dan saling menjaga antara orang tua-anak akan berdampak pada pembentukan karakter positif anak. 
Nilai CR dan AVE menunjukkan reliabilitas alat ukur. Secara keseluruhan, variabel laten pada second order menunjukkan hasil yang memiliki reliabilitas yang tinggi, yaitu di atas 0,7 . Hal ini seperti pada beberapa riset tentang keluarga yang melakukan pengukuran (Andreina, 2017) yang menunjukkan skor diatas 0,7 sehingga dapat disimpulkan alat ukur memiliki reliabilitas yang tinggi.

\section{SIMPULAN DAN SARAN}

Secara keseluruhan, dapat disimpulkan bahwa skala keharmonisan keluarga FHS-24 merupakan alat ukur yang valid dan reliabel yang dapat digunakan untuk mengukur keharmonisan keluarga di Indonesia. Kelima indikator yaitu: forbearance (kesabaran), conflict resolution (resolusi konflik), communication (komunikasi), identity (identitas keluarga), dan quality time (waktu yang berkualitas bersama keluarga). Hasil penelitian ini mencerminkan variabel laten yang diukur (keharmonisan keluarga) dan juga masingmasing pernyataan pada masing-masing indikator menunjukkan angka validitas yang baik. Semua parameter kesesuaian model juga menunjukkan bahwa model FHS-24 fit/cocok/sesuai untuk mengukur keharmonisan keluarga pada responden di Indonesia.

Meskipun begitu, penelitian ini juga memiliki beberapa keterbatasan, antara lain mengenai jumlah responden yang kurang dan tidak membedakan antara responden pada suku/budaya yang berbeda yang bisa menghasilkan penjelasan yang lebih bisa membedakan kondisi keharmonisan keluarga secara lebih luas dan spesifik. Penelitian selanjutnya dapat mengembangkan skala keharmonisan keluarga dengan jumlah contoh yang lebih besar untuk mengukur reliabilitas dan validitas skala keharmonisan keluarga FHS-24, atau membuat skala keharmonisan keluarga lebih lanjut, mengingat baru satu alat ukur keharmonisan keluarga yang ditemukan publikasinya. Penelitian keharmonisan keluarga masih membutuhkan banyak pengembangan tentang alat ukur, dapat dilakukan dengan melakukan replikasi dengan responden yang berbeda budaya atau membedakan antara responden suami, istri, dan anak agar menunjukkan hasil yang lebih komprehensif.

\section{DAFTAR PUSTAKA}

Akbar, R. (2020). Angka Perceraian Meningkat Kemenag Kerjasama dengan BP4. Retrived

from www.alinea.id/nasional/angka-perceraianmeningkat-kemenag-kerjasama-denganbp4b1ZT59xdU. Diakses pada September 2020.

Andreina, L., Kusyanti, A., \& Rokhmawati, R. I. (2017). Analisis faktor-faktor yang memengaruhi niat pengguna internet untuk menggunakan fungsi single sign on google dengan metode SEM (structural equation modeling). Jurnal Pengembangan Teknologi Informasi dan IImu Komputer (JPTIIK) Universitas Brawijaya, 1(10), 1100 1109.

Anjassari, W. M., Rustiyarso., \& Budjang, G. (2015). Analisis keharmonisan keluarga petani melayu dalam membentuk kepribadian anak di Desa Nanga Suhaid. Jurnal Pendidikan dan Pembelajaran Katulistiwa, 4(3), 1-15.

Asilah, A., \& Hastuti, D. (2013). Hubungan tingkat stres ibu dan pengasuhan penerimaan penolakan dengan konsep diri remaja pada keluarga bercerai. Jurnal IImu Keluarga dan Konsumen, 7(1), 10-18. doi: 10.24156/jikk.2014.7.1.10.

Asoodeh, M. H., Daneshpour, M., Khalili, S., Lavasani, M. G., Shabani, M. A., \& Dadras, I. (2011). Iranian successful family functioning: Communication. Procedia Social and Behavioral Sciences, 30, 367371. doi: 10.1016/J.SBSPRO.2011.10.072.

Bakar, A. A., \& Afthanorhan, A. (2016). Confirmatory factor analysis on family communication patterns measurement. Procedia - Social and Behavioral Sciences, 219(2016), 3340. doi: 10.1016/j.sbspro.2016.04.029.

Berlianti, D., Vitalaya, A., Hastuti, D., Sarwoprasojdo, S., \& Krisnatuti, D. (2017). Ada apa dengan komunikasi orang tuaremaja?: Pengaruhnya terhadap agresivitas remaja pada sesama. Jurnal IImu Keluarga dan Konsumen, 9(3), 183194. doi: $10.24156 / j i k k .2016 .9 .3 .183$.

[BKKBN] Badan Kependudukan dan Keluarga Berencana Nasional. (2015). Rencana Strategis Badan Kependudukan dan Keluarga Berencana Nasional 2015-2019. Retrieved from www.bkkbn.go.id/pocontent/uploads/RENSTRA-BKKBN-20152019.pdf. Diakses tanggal 9 April 2019.

Chuang, Y. C. (2005). Effects of interaction pattern on family harmony and well-being: Test of interpersonal theory, relationalmodels theory, and confucian ethics. Asian 
Journal of Social Psychology, 8(3), 272$291 . \quad$ doi: $10.1111 / \mathrm{j} .1467-$ 839X.2005.00174.x.

DeFrain, J., \& Stinnett, N. (2002). Family strengths. In J. J. Ponzetti, Jr. (Ed.), International Encyclopedia of Marriage and Family (2nd ed., pp. 637-642). New York, NY: Macmillan Reference Group.

Fauziah, N. (2020). The concept of family's harmony in multiple cultural settings, what about the family harmony with autism children in indonesia? A literature study. The Family Journal: Counseling and Therapy for Couples and Families, 8(4), 16. doi: $10.1177 / 1066480720904027$.

Fiske, A. P. (1992). The four elementary forms of sociality: Framework for a unified theory of social relations. Psych Rev, 99(4), 6897239. doi: 10.1037/0033-295x.99.4.689.

Ghozali, I. (2018). Struktural equation modeling: Teori, konsep dan aplikasi dengan Program Lisrel 9.10, (Edisi 4). Semarang, ID: Badan Penerbit Undip.

Gunarsa, S. D. (2005). Psikologi Untuk Keluarga. Jakarta, ID: BPK Gunung Mulia.

Hair Jr., J. F., Anderson, R. E., Tatham, R. L., \& Black, W. C. (1998). Multivariate Data Analysis (5th ed.). Upper Saddle River, NJ: Prentice Hall.

Handayani, N., \& Fauziah, N. (2016). Hubungan keharmonisan keluarga dengan kecerdasan emosional pada guru bersertifikasi sekolah menengah atas swasta berakreditasi A wilayah Semarang Barat. Empati: Jurnal Karya IImiah S1 Undip, 5(2), 408-412.

Hawari, D. (2010). Al-quran ilmu kedokteran jiwa dan kesehatan mental. Jakarta, ID: Dana Bhakti Yasa.

Herawati, N., Setyaningsih., \& Herlambang, S. M. (2019). Peran dukungan keluarga dan keharmonisan perkawinan orangtua dalam pendidikan spiritual anak. Jurnal Wacana, 11(2), 213-221. doi: 10.13057/wacana.v11i2.147.

ITC guidelines for translating and adapting tests (2nd edition). (2017). International Journal of Testing, 18(2), 101-134. doi: 10.1080/15305058.2017.1398166.

Kavikondala, S., Stewart, S. M., Ni, M. Y., Chan, B. H. Y., Lee, P. H., Li, K.-K., McDowell, I., Johnston, J. M., Chan, S. S., Lam, T. H., Lam, W. W. T., Fielding, R., \& Leung, G. M. (2016). Structure and validity of family harmony scale: An instrument for measuring harmony. Psychological Assessment, 28(3), 307-318. doi: $10.1037 /$ pas 0000131 .

Kementerian Hukum dan HAM. (2016). Peraturan Menteri Pemberdayaan

Perempuan Nomor 2 Tahun 2016.

Retrieved from

www.ditjenpp.kemenkumham.go.id.

Diakses tanggal 9 April 2019.

Khadifa, L., \& Sugihen, B. T. (2018). Hubungan antara keharmonisan keluarga dan kehadiran belajar siswa di sekolah menengah atas (SMA) negeri 5 di kota banda aceh. Jurnal Ilmiah Mahasiswa FISIP Unsyiah, 3(1), 316330.

[KPPPA \& BPS] Kementerian Pemberdayaan Perempuan dan Perlindungan Anak \& Badan Pusat Statistik. (2016). Pembangunan Ketahanan Keluarga 2016. Retrieved from https://www.kemenpppa.go.id/lib/uploads/li st/9455b-buku-pembangunan-ketahanankeluarga-2016.pdf. Diakses tanggal 9 April 2019.

Lam, W. W. T., Fielding, R., McDowell, I., Johnston, J., Chan, S., Leung, G. M., \& Lam, T. H. (2012). Perspectives on family health, happiness and harmony $(3 \mathrm{H})$ among Hong Kong Chinese people: a qualitative study. Health Education Research, 27(5), 767-779. doi: 10.1093/her/cys087.

Lombardi, C. M. P. (2021). Family income and mothers' parenting quality: Within-family associations from infancy to late childhood. Children and Youth Services Review, 120(2020), $105799 . \quad$ doi: 10.1016/j.childyouth.2020.105799.

Moos, R. J., \& Moos, B. S. (1981). Family environment scale. Paolo Alto. CA: Consulting Psychologists' Press.

Muhammad, L. Y. B., Muflikhati, I., \& Simanjuntak, M. (2019). Religiusitas, dukungan sosial, stres, dan penyesuaian wanita bercerai. Jurnal Ilmu Keluarga dan Konsumen, 12(3), 194-207. doi: 10.24156/jikk.2019.12.3.194.

Nur, A. S., \& Bahriyah, E. N. (2008). Komunikasi lintas budaya dalam perspektif perilaku konsumen. Jurnal Komunikologi, 5(2), 192-200.

Nuraini, A., \& Hartini, N. (2021). Peran acceptance and commitment therapy (ACT) untuk menurunkan stres pada family caregiver pasien kanker payudara. Jurnal IImu Keluarga dan Konsumen, 14(1), 27- 
39. doi: 10.24156/jikk.2021.14.1.27.

Partiyem. (2016). Hubungan keharmonisan keluarga dengan hasil belajar mata pelajaran prakarya siswa sekolah menengah pertama Patean. KELUARGA: Jurnal IImiah Pendidikan Kesejahteraan Keluarga, 2(1), 31-40. doi: 10.30738/keluarga.v2i1.1815.

Pasaribu, R. M., Hastuti, D., \& Alfiasari, A. (2013). Gaya pengasuhan permisif dan rendahnya sosialisasi nilai dalam keluarga berisiko terhadap penurunan karakter remaja. Jurnal IImu Keluarga dan Konsumen, 6(3), 163-171. doi: 10.24156/jikk.2013.6.3.163.

Perry, A., Harris, K., \& Minnes, P. (2012). Family environments and family harmony: An exploration across severity, age, and type of DD. Journal on Developmental Disabilities, 11(1), 17-29.

Pottas, S. (2009). An exploratory study of family harmony in family businesses (Minidissertation, The North-West University, Potchefstroom Campus, South Africa). Retrieved from https://repository.nwu.ac.za/bitstream/hand le/10394/4159/pottas_s.pdf?sequence $=1$.

Rahayu, K. S. I., Zikra, \& Yusri. (2013). Hubungan antara keharmonisan keluarga dan motivasi belajar siswa. Jurnal IImiah Konseling, 2(1), 191-196. doi: 10.24036/0201321909-0-00.

Respati, A. D., Muhariati, M., \& Hasanah, U. (2014). Hubungan antara ketahanan keluarga dengan kenakalan remaja. JKKP (Jurnal Kesejahteraan Keluarga dan Pendidikan), 1(2), $41 . \quad$ doi: 10.21009/JKKP.012.07.

Rioux, C., Ryan, N. C., Parent, S., \& Seguin, J. R. (2016). The interaction between temperament and the family environment in adolescent substance use and externalizing behaviors: Support for diathesis-stress or differential susceptibility?. Developmental Review, 40(2016), 117-150. doi: 10.1016/j.dr.2016.03.003.

Rizak, M. (2018). Peran pola komunikasi antarbudaya dalam mencegah konflik antar kelompok agama. IsLam et alic Communication Journal, 03(1), 88-104. doi: 10.21580/icj.2018.3.1.2680.

Saputri, E. M. (2014). Hubungan interaksi sosial dan keharmonisan keluarga dengan perilaku agresif pada siswa kelas X SMK Negeri 1 Baureno-Bojonegoro. Jurnal BK UNESA, 4(1), 375-382.

Septiana, V. S., Krisnatuti, D., \& Simanjuntak, M. (2014). Faktor suku dalam pola komunikasi, penyesuaian suami istri, dan keharmonisan keluarga. Jurnal IImu Keluarga dan Konsumen, 7(1), 1-9. doi: 10.24156/jikk.2014.7.1.1

Sharif, M. S. M., Zahari, M. S. M., Nor, N. M., \& Muhammad, R. (2015). The significance of hari raya food towards Malay community in Malaysia. Procedia - Social and Behavioral Sciences, 201(2015), 175-181. doi: 10.1016/j.sbspro.2015.08.166.

Soltani, A., Hosseini, S., \& Mahmoodi, M. (2013). Predicting Identity style based on family communication pattern in young males. Procedia - Social and Behavioral Sciences, 84(2013), 1386-1390. doi: 10.1016/j.sbspro.2013.06.761.

Wilson, J., \& Tonner, A. (2020). Doing family: The constructed meanings of family in family farms. Journal of Rural Studies, 78(2020), 245-253. doi: 10.1016/j.jrurstud.2020.06.002.

Zarnaghash, M., \& Zarnaghash, N. (2013). The relationship between family communication patterns and mental health. Procedia Social and Behavioral Sciences, 84(2013), 405-410.

doi: 10.1016/j.sbspro.2013.06.575 